\title{
PEQUENOS ENREDOS NAS ESCOLAS PARQUE DE BRASÍLIA: O QUE CONTAM AS CRIANÇAS SOBRE A AULA DE MÚSICA
}

\author{
Children in the schools park of Brasilia: what children do \\ about the music school
}

\author{
Olívia Augusta Benevides Marques \\ Universidade de Brasília \\ oliviamarques11@gmail.com \\ DELMARY VASCONCELOS DE ABREU \\ Universidade de Brasília \\ delmaryabreu@gmail.com
}

\begin{abstract}
Resumo: Este artigo é o resultado de uma pesquisa de mestrado concluída que buscou compreender, por meio das narrativas, como as crianças dos anos iniciais veem as aulas de música nas Escolas Parque de Brasília. Baseado nos estudos da Sociologia da Infância de Manoel Sarmento, a pesquisa utiliza os conceitos da criança como ator social e culturas da infância. A metodologia empregada consiste no método (auto)biográfico cujas fontes são as narrativas infantis. Como instrumento de coleta de informações, optamos pelas Rodas de Conversa. Diante dos pequenos enredos construídos com as crianças colaboradoras da pesquisa, compreendemos com suas narrativas o tipo de escola e aula de música desejados: uma escola divertida, que acolhe, ensina musicalmente e constrói valores para a vida. As narrativas infantis escutadas poderão gerar um novo modo de ouvir histórias produzidas no espaço escolar com crianças e com músicas. Isso possibilita que ideias, proposições e, quem sabe, conceitos e principios possam emergir conhecimentos gerados a partir das narrativas infantis.
\end{abstract}

Palavras-chave: Escolas Parque. Anos iniciais. Narrativas infantis.

\begin{abstract}
This article is the result of a completed master's research that sought to understand through the narratives, how the children of the early years see the music classes in the Park Schools of Brasilia. Based on the studies of the Sociology of Childhood of Manoel Sarmento the research uses the concepts of the child as a social actor and cultures of childhood. The methodology used is the (Auto) Biographical Research, and as an instrument of information gathering, the Conversation Wheels. Within the (Auto) biographical perspective it was possible to construct explanatory principles to think with the student what kind of school, teachers and music class we want. The children's narratives heard here may generate a new way of listening to stories produced in the school space with children and music. This allows ideas, propositions and, perhaps, concepts and principles to emerge knowledge generated from children's narratives.
\end{abstract}

Keywords: Park schools. Initial years. Children's narratives. 


\section{INTRODUÇÃO}

Este trabalho é uma sintese dos resultados de análise de uma pesquisa concluída no ano de 2017, em um mestrado acadêmico no Programa de PósGraduação em Música da Universidade de Brasília. Ao dialogar com a literatura da área da educação musical, busquei problematizar, de dentro da área, aquilo que a experiência já havia anunciado como professora licenciada em música e atuante no contexto escolar há mais de vinte anos.

Na experiência em sala de aula, deparamo-nos com situações de ensino em que se percebia que as crianças, muitas vezes, não demonstravam interesse em se apropriarem das propostas construídas para os projetos de música na escola. Fomos percebendo que durante esses anos as crianças não tinham espaço para se manifestarem sobre as aulas de música.

Constatar que as crianças não eram escutadas sobre aquilo que ensinamos como professores de música nos levou a refletir sobre as próprias práticas pedagógico-musicais. Isso nos levou a indagações sobre qual é a visão que as crianças têm das aulas de música: O que as crianças teriam a dizer sobre o modo como vivenciam as experiências musicais na escola? Como as crianças interpretam a aula de música? Como imaginam que deveria ser a aula de música na escola? Essas inquietações nos levaram ao objetivo da pesquisa: compreender como crianças dos anos iniciais veem as aulas de música nas Escolas Parque de Brasília.

Encontramos pesquisas relacionadas a essa temática sob diferentes perspectivas. Destacamos a de Heinkel (2010) pelas afinidades com esta pesquisa, uma vez que a referida autora constata que a criança nos diz muito, mas que, ao mesmo tempo, nos interroga e que nem sempre conseguimos apreender o que dizem por causa do nosso olhar adultocêntrico, que não nos permite enxergar a sabedoria infantil de ser e viver neste espaço socializado de saberes, que é o espaço escolar. Heinkel (2010, p. 110) entende que "este novo olhar para a criança 'desarruma' as velhas lógicas do ser e estar professor, porque ela também sabe nos dizer o que é bom para ela". Escutar a voz da criança diz muito, desafia A escuta das vozes da criança diz muito, desafiando as "práticas pedagógicas", significando que "o que conta é o melhor para a criança, e não para o professor ou a escola” (Heinkel, 2010, p. 110).

Ainda a respeito de pesquisas realizadas com crianças, Ponso (2011) objetivou verificar de que modo as práticas infantis de brincar, jogar e descobrir elementos musicais nas experiências cotidianas, e que oportunidades, contextos e experiências auxiliam as crianças na formação do conhecimento musical. A referida autora esclarece que foi fundamental ouvir as crianças na investigação e sugere mais pesquisas voltadas para uma sociologia da infância que pressuponha ouvir os alunos, uma voz ativa que permita a condução da história discente por suas próprias relações com o conhecimento musical. 
Encontramos ressonâncias na pesquisa de Pedrini (2013) pela abordagem teórico-metodológica da pesquisa (auto)biográfica com crianças. Embora as demais pesquisadoras supramencionadas também tivessem como objetivo ouvir as crianças, entendemos que a pesquisa com narrativas vai um pouco mais além, pelo fato de ser construída com o aluno. Nas palavras de Passeggi (2014, p. 133), "nada para a criança, sem a criança, expressando o desejo de evidenciar a alteridade da criança, reivindicando com ela, a legitimidade do que diz sobre si e sobre a escola, como algo digno de interesse em matéria de educação [musical]". Os argumentos da referida autora nos levam a pensar que tendemos a diluir, substituir ou mesmo silenciar a palavra e a música da criança, bem como as questões que ela coloca para a educação musical escolar. Portanto, evidenciar o que a criança diz sobre si e sobre a escola, por meio das suas narrativas com a música, tornou-se o objeto da pesquisa realizada.

O campo de pesquisa foi constituído pelas cinco Escolas Parque (EP) situadas no Plano Piloto da cidade de Brasília (DF). As EPs que integram a Rede Pública de Ensino do Distrito Federal são consideradas pela Secretaria de Estado de Educação do Distrito Federal SEDF como escolas de natureza especial, cujas tipologias de atendimento são diferenciadas das Escolas Regulares da Rede Pública de Ensino. Essas unidades ofertam os componentes curriculares: Arte (artes plásticas/visuais, música, artes cênicas, dança, literatura) e Educação Física, com atendimento especializado, integrando o currículo de, no mínimo, cinco unidades escolares. Os critérios de participação adotados na pesquisa foram crianças do quinto ano das cinco Escolas Parque de Brasília. Utilizamos as aspas por entender que a pesquisa se daria "com" a criança, e não "sobre" ela; este foi o maior desafio assumido.

\section{PRESSUPOSTOS TEÓRICOS}

Para aclarar o nosso olhar sobre o objeto investigado - a compreensão das crianças sobre o ensino de música nas EPs de Brasília -, recorremos aos conceitos tratados por Sarmento (1997), que abordam as culturas da infância e a participação das crianças em pesquisas.

O autor mencionado enfatiza que o estudo de crianças, a partir de si mesmas, permite descortinar uma realidade social que emerge das interpretações infantis dos respectivos mundos de vida. O olhar das crianças permite revelar fenômenos sociais obscurecidos pelo olhar dos adultos e interpretar as representações sociais das crianças, que podem ser não apenas um meio de acesso à infância como categoria social, mas também às próprias estruturas e dinâmicas sociais, que são "desocultadas" no discurso [musical] das crianças. Essas vozes que permaneceram ocultas nos métodos tradicionais de investigação são recuperadas pela presença da criançaparceira no trabalho interpretativo, mobilizando para tal um discurso polifônico e cromático, que resulta da voz e da ação da criança em todo o processo. 
De acordo com Sarmento (2004), existem quatro eixos estruturadores das culturas da infância. O primeiro é a interatividade: as crianças aprendem com as outras crianças nos espaços de partilha comum, estabelecendo, assim, as culturas de pares que permitem às crianças apropriar, reinventar e reproduzir o mundo que as rodeia. O segundo é a ludicidade que, para as crianças, não há distinção entre brincar e fazer coisas sérias. A fantasia do real, terceiro eixo, consiste no mundo do faz de conta da criança, da sua visão do mundo e da atribuição do significado às coisas - que o autor chama de um modo de inteligibilidade. A transposição imaginária de situações, pessoas, objetos ou acontecimentos está na base da constituição da especificidade dos mundos das crianças. O quarto eixo consiste na reiteração, em que o tempo da criança é recursivo, exprimindo-se em contínua recriação das mesmas situações e rotinas, por meio da transmissão de brincadeiras das crianças mais velhas para as mais novas.

$\mathrm{Na}$ contemporaneidade, e à luz dos conceitos de Sarmento (2004), entendemos que essas reconfigurações da infância são reinventadas, fazendo das crianças contemporâneas construtoras ativas do seu próprio lugar na sociedade.

\section{ABORDAGEM METODOLÓGICA E TÉCNICA DE PESQUISA}

Este tópico discorre sobre a metodologia empregada, a técnica da pesquisa, os colaboradores da pesquisa e o tipo de análise utilizada.

Alimentado por uma ampla tradição hermenêutica e fenomenológica, o método (auto)biográfico estabelece uma reflexão sobre o agir e o pensar humanos mediante figuras orientadas e articuladas no tempo que organizam e constroem a experiência segundo a lógica de uma razão narrativa. De acordo com essa lógica, Delory-Momberger (2012) enfatiza que o individuo humano vive cada instante de sua vida como o momento de uma história: história de um instante, história de uma hora, de um dia, de uma vida.

A forma de expressão mais imediata para demonstrar a representação mental, pré-escritural de uma biografia são as narrativas. Assim, ao narrar um acontecimento, a pessoa reorganiza sua experiência, de modo que ela tenha ordem coerente e significativa, dando um sentido ao evento. Por meio das narrativas, podemos de modo indireto ter acesso à experiência do outro, pois a pessoa traz a sua experiência da maneira como ela a percebe, ou melhor, da maneira como a interpreta.

A Pesquisa (Auto)biográfica é fundada na relação entre formação e aprendizagem. Há um mundo da educação que está em relação contínua com os outros setores da vida social, mas, ainda assim, há um espaço singular das experiências vividas (Delory-Momberger, 2011)

Encontramos em Abreu (2011), definições desse método utilizado na área de educação musical. A referida autora esclarece que o que interessa ao pesquisador da educação musical é o ponto de vista do sujeito, isto é, como 
ele interpreta as suas compreensões nas escolhas do que julga importante informar da sua relação com a música.

Nessa direção, as crianças colaboradoras da pesquisa, que têm aulas de música na escola - neste caso, nas cinco Escolas Parque de Brasília -, trazem, através do seu percurso formativo no contexto escolar, narrativas orais, cujas singularidades e experiências com a música no espaço escolar fazem emergir uma experiência de grupo. Desse modo, para capturar as narrativas das crianças colaboradoras, utilizamos, como técnica de pesquisa, as Rodas de Conversa ( $\mathrm{RC})$, por terem uma característica de partilha de experiências. De acordo com Moura (2014), no âmbito da pesquisa narrativa, o pesquisador se insere pela interação nas conversas, produzindo, ao mesmo tempo, as informações na discussão.

Por uma questão ética e por serem crianças, optamos por identificá-los por nomes de personagens de histórias em quadrinhos. As crianças colaboradoras escolheram os seus personagens favoritos.

Inspirando-nos no trabalho de Passeggi (2014), utilizamos um protocolo que consistia na apresentação de um boneco, personagem de histórias em quadrinhos, que vivia em um planeta sem escolas. Passeggi (2014) esclarece que nas pesquisas que têm como foco de produção e de análise as narrativas das crianças, é necessário criar um espaço lúdico em que sejam oferecidas ferramentas semióticas, tais como contos, desenhos e brinquedos, para que a criança possa se expressar, pensar sobre si mesma ou sobre o mundo, para, enfim, narrar. O espaço lúdico visa privilegiar a naturalidade e a espontaneidade no ato de narrar.

Para esse tipo de partilha de narrativas em Rodas de Conversa com crianças, necessita-se, segundo Passeggi (2014), de um diferencial na recolha das fontes. Nas RC, as crianças dialogavam com um pequeno boneco. $\mathrm{O}$ boneco escolhido foi o Thor, criação do escritor Stan Lee, pelo enorme sucesso da franquia Os Vingadores por se aproximar do universo infantil como ferramenta semiótica.

\section{A INTERPRETAÇÃO DOS PEQUENOS ENREDOS}

O desafio hermenêutico na interpretação das narrativas das crianças tem exigido muito cuidado para que, ao nos aproximarmos da sua visão de mundo, não nos deixemos envolver por aspectos técnicos que possam prejudicar a nossa compreensão do modo de pensar da criança (Passeggi, 2014).

Foi a partir dessas histórias narradas que organizamos pequenos enredos, intitulados como: 1) Escola Parque como segunda casa; 2) Música na Escola Parque é para ser divertida; 3) Professores da Escola Parque ensinam música e valores para a vida. Consideramos, com cuidado, palavraschave que se destacavam nas narrativas de diferentes colaboradores, procurando manter no corpo do enredo os temas centrais das narrativas. 
Fizemos uma sintese do heterogêneo que agregavam às narrativas os sentidos daquilo que se faz com a palavra do outro (DELORY-MOMBERGER, 2012, p. 529).

No primeiro momento, a palavra-chave que mais chamou atenção foi "diversão". Depois fomos percebendo que a diversão estava associada às atividades feitas durante a aula, como tocar, cantar e criar. Ao contarem o que gostavam e o que não gostavam na aula de música, as crianças também se posicionaram, nos termos de Delory-Momberger (2012, p. 534), "numa atitude de exploração das situações e de construção progressiva", categorizado pela autora como "um agir progressivo", dando pistas do que é e do que não é necessário ter na aula de música. A seguir, apresentaremos parte dos resultados da pesquisa intitulando nos subtópicos os temas que emergiram para a análise.

\section{"EU ACHO A ESCOLA PARQUe LEGAL PORQUE TEM AULAS DIVERTIDAS”}

A palavra "diversão" foi surgindo espontaneamente das narrativas. Ao inscrever em suas narrativas a palavra "diversão", o fazer musical em sala de aula se torna algo prazeroso de se realizar: "Eu acho divertida a EP porque você aprende música, educação física, artes, teatro. O que eu mais gosto é música, mas eu acho os outros legais também" (Carminha Frufru1); "Uma aula divertida e que ensina a tocar" (Isadora); "É divertido porque você aprende a tocar novas coisas..." (Magali 1); "É uma música bem legal só para divertir os alunos" (Franjinha).

No agir progressivo das crianças narradoras, a diversão estava intrinsecamente relacionada às atividades da aula de música: tocar, cantar, criar e compor, ligadas ao ensino e aprendizagem: "A aula de música é boa porque a gente aprende muita coisa, aprende as notas musicais, a tocar instrumentos, a cantar sem vergonha das pessoas" (Flash); "Eu gosto quando a gente toca instrumento, todo mundo junto, e todo mundo participa, é muito legal. Quando a gente toca o instrumento, a gente fica com a [música] na cabeça" (Magali 1); "A gente bate [toca], a gente bate" (Aninha), e Carmem complementa: "A gente canta". Franjinha também conta na RC que "a gente inventa música, a gente inventa toques [...] e cria toque, canta, inventa instrumentos".

As crianças colaboradoras da pesquisa também quiseram expressar na aula de música a relação com outras áreas artísticas. Mônica trouxe em sua narrativa a dança como uma prática a ser realizada na aula de música: "Ele [o professor] também podia ensinar a gente a dançar, porque aula de música não é só para cantar e tocar instrumentos, também serve para dançar aquela música". Denise entende que a dança e o teatro complementam o fazer musical: "É tocar instrumentos, cantar e dançar na aula de música. A gente 
toca instrumentos, faz um pouco de teatro mexendo bonecos. Uma das partes que mais gostei foi quando fiquei com um boneco chamado Pirulito".

$\mathrm{Na}$ visão das crianças colaboradoras, as diferentes especificidades das artes não estão apartadas da música, pelo contrário, elas integram o fazer musical. Esse é um modo como o professor de música, com o pseudônimo Tocha Humana, de uma dessas escolas integra em seus projetos musicais as diferentes linguagens. Essa integração se assemelha à pedagogia de projetos divulgada por Teixeira (1975), que acreditava que o ensino poderia ser dado por meio de projetos, ao invés de "lições". Esses projetos não acompanhariam, segundo ele, a sequência lógica de divisão das disciplinas, mas poderiam se organizar em consonância com os interesses e capacidades da criança. Isso faz com que "a criança chegue a um alto grau de organização científica", a partir da construção do seu próprio conhecimento (Teixeira, 1975, p. 80) - o que também remete às palavras de Alheit (2011, p. 34), pois "somos nós que percorremos um processo de aprendizagem. Não existem substitutos para os processos de aprendizagem". Portanto, é a criança quem toma as rédeas de sua experiência formativa.

Trazemos também um recorte das narrativas que ilustram aquilo que os colaboradores gostam e o que não é tão prazeroso fazer na aula de música. Sobre o que gostam de fazer na aula de música, as narrativas mostram que tocar, cantar e criar ritmos musicais são as preferências da maioria dos colaboradores:

E umas das coisas que eu mais gosto é tocar teclado e cantar (Mônica).

Eu gosto de cantar. A coisa que eu mais gosto é cantar e tocar instrumentos, né! (Carminha Frufru1).

A coisa que mais gosto de fazer na aula de música é tocar os instrumentos. Fazer. Tocar a música que o professor toca, que o professor pede para tocar. Cantar música (Flash).

Eu gosto de cantar... (Isadora).

[...] Eu gosto de ficar só com um instrumento e tocar só um instrumento (Franjinha).

Inventar novos ritmos (Isadora).

Eu geralmente só gosto de fazer ritmos, eu gosto de tocar copos, fazer ritmos com a mão, ficar no chão sentado (Franjinha).

Eu gosto de tocar no metalofone, na garrafa e no teclado (Hulk).

Eu gosto de tocar teclado (Viúva Negra). 
Eu gosto de tocar no metalofone, na garrafa e no negocinho que faz barulho... É... no chocalho... É... metalofone (Capitão América).

Nos relatos acima é possivel perceber como acontece a aula de música nessas EP. Ao que parece, as aulas são bastante musicais e permeadas pelo prazer de saber-fazer. Isso é esclarecido por Mônica: "Eu gosto muito da aula de música, porque eu aprendi a tocar teclado". Como disse Flash, a aula de música é para "aprender as coisas". E essa motivação para aprender a tocar um instrumento se amplia para além do espaço escolar quando Carminha Frufru1 relata: "Eu sempre quis aprender violão, agora eu estou tentando aprender com o meu pai". Portanto, a relação que esses colaboradores constroem com a música os ajuda a vencer outras limitações, como narraram Denise, Mônica e Carminha Frufru1:

Antes eu tinha muita vergonha, mas, agora que eu fiz aula de música, comecei a apresentar nos palcos, comecei a tocar mais, agora eu perdi a vergonha toda e estou começando a tocar mais até em casa. Minha mãe comprou um teclado para mim e agora eu estou tocando para os meus pais (Denise).

Eu gosto muito da aula de música, porque ela me fez perder o medo de palco. Quando eu entrei no projeto, eu tinha, eu morria de vergonha, só que, quando a gente apresentou a primeira, eu me senti livre, e eu comecei a falar tudo o que eu sentia, e foi muito legal" (Mônica).

Quando eu entrei na aula de música, tinha muita vergonha, não conseguia nem ficar na frente da minha mãe, e no dia que eu fui apresentar com o meu professor eu tinha que falar na frente e tinha que tocar. Aî, depois daquele dia, eu passei a não ter mais vergonha (Carminha Frufru1).

Entre as situações que não são tão agradáveis na aula de música, alguns colaboradores trazem em suas narrativas algumas situações de ensino:

Quando troca para outro instrumento, eu não consigo. É chato. Odeio trocar de instrumento (Franjinha).

Também de cantar na aula de música. Geralmente eu não gosto tanto da aula de música por causa... faz muito barulho. (Aninha).

É, eu também não gosto [de barulho] (Pipa).

Todo mundo gosta da aula de música, mas ninguém gosta do instrumento xilofone, que ele é muito chato, muito zuadento, enjoativo, fica fazendo muito barulho (Mulher Maravilha2). 
Nessas narrativas podemos perceber que os colaboradores gostam de fazer música em sala de aula, porém, o que incomoda, como apontaram Franjinha, Aninha, Pipa e Mulher Maravilha2, é o barulho, algo bastante comum nas aulas de música. Nesse sentido, uma vez que a matéria-prima da música é o som, a organização de estratégias de ensino é o maior desafio para o professor de música, pois o "som" pode atrapalhar a aprendizagem.

Essas estratégias de ensino podem ajudar naquilo que Magali1 relata: "O tempo da aula de música é muito precioso". E esse tempo, muitas vezes, é absorvido não só pela falta de estratégias de ensino, mas também pelas relações entre os colegas de sala de aula, como narram.

O que não gosto é quando a gente briga entre a gente, [porque] a gente perde o tempo da aula, e o tempo da aula de música é muito precioso. E o que eu não gosto é a mesma coisa da Denise: quando a gente briga, a gente pede silêncio, faz tudo errado e perde muito tempo da aul (Magali1).

E eu não gosto quando o professor grita pedindo silêncio, aí perde o tempo da aula, essas coisas (Carminha Frufru1).

Além desses incômodos, Marina1 acrescenta o seguinte: "O que eu não gosto na aula de música é de não se soltar, a pessoa não se solta, fica lá parada e não faz nada. Isso é ruim. Quando você se solta, você sente um trem tão grande, que é muito bom". Essa narrativa pode ser aclarada com o que afirma Merriam (1964) sobre as funções da música na sociedade. O autor explica que a função da expressão emocional que a música exerce é a expressão da liberação dos sentimentos, uma forma de desabafo de emoções através da música, o que, nas palavras de Marina1, "é muito bom".

\section{"UMA ESCOLA COM VIDA"}

O recorte aqui empreendido traz relatos oriundos da temática: Professores da EP ensinam música e valores para a vida". Evidenciamos as memórias dos colaboradores sobre o que pensam dos professores da EP e das aulas de música. Das lembranças trazidas em narrativas, destacamos os seguintes relatos:

Quando eu estava no primeiro ano, é... eu tinha uma aula de música, que tinha uma música que eu tinha que ensaiar. Eu não gostava daquela música, mas eu tinha que ensaiar. Aí, quando chegou no segundo ano, eu estava com o mesmo professor. Era uma professora, e ela me forçava a ensaiar. Eu não gostava daquela música. $\mathrm{E}$, quando chegou no terceiro ano, a mesma professora. Aí eu comecei a gostar daquela música, porque, de tanto que eu gostava ficou na minha cabeça. Fiquei cantando três dias seguidos no meu sonho. Eu sonhei com aquela música (Carminha Frufru1). 
Outras narrativas como a de Cebolinha também fazem referência às memórias musicais do espaço escolar: "Quando eu estava no primeiro ano, fui aluno seu, a gente fez apresentação das músicas do Toquinho e foi muito legal". Marina1 relembra: "Uma música que me marcou muito foi da abelha, que aprendi no quarto ano. Apresentei com a professora Tina. Essa música me marcou muito".

Segundo Benjamin (1987), a memória tem a função de efetivar a compreensão do passado pelo presente. O tempo é a atualização das experiências, dos sentimentos, das vivências, e a representação do sujeito no agora. Nas narrativas dos colaboradores podemos ver as lembranças trazidas sobre um tempo em que tiveram aula de música na escola e como constroem seus pontos de vista sobre o assunto, a partir da experiência vivida. São marcas que ficaram, como narrou Marina1: "Essa música me marcou muito". A forma como Carminha Frufru1 relata uma sequência de eventos que se repetiram do primeiro ao terceiro ano do ensino fundamental levou-a a atualizar sua experiência com determinada música. Essas ressonâncias significam dizer que não fazemos pequenos enredos porque se tem uma experiência musical vivida com a escola, tem-se uma experiência musical porque construímos pequenos enredos do que contamos sobre o vivido na escola.

As lembranças musicais trazidas nas RC pelos colaboradores mostram o lugar que a escola, especificamente a música da escola, ocupa em suas vidas. Narra-se o que é vivido, e essas vivências deixam rastros no percurso percorrido por essas crianças. Esse agir progressivo, como narrou Carminha Frufru1, de ter experiências com a mesma música, produziu pequenos saltos em seu olhar sobre si mesma. Isso nos remete a Larrosa Bondía (2002) dizer que somente o sujeito da experiência está aberto à sua própria transformação.

A idealização que as crianças colaboradoras fazem sobre o professor de música da EP é carregada de palavras como amor e alegria:

Um professor... Ele tem que ter vontade de dar aula, porque tem professor que não tem, [que] coloca qualquer coisa e está bom. E também saber falar português, não marciano, e ter amor, alegria, chegar sempre no bem-estar na escola (Magali1).

Tem que ter uns bons professores. Ter uns com a alegria de sempre. E sempre termos um bom carinho pelos professores (Flash).

Os colaboradores idealizam um professor que tem amor pelo que faz; neste caso, dar aula de música com prazer e ser claro na sua comunicação. Nas palavras dos colaboradores, para ensinar música, a linguagem utilizada pelo professor em sala de aula tem de ser elaborada de forma que leve o aluno à compreensão. É, no entanto, mais um modo de ser e agir em sala de aula cujas estratégias de ensino levem o aluno a outra margem do conhecimento. 
Para que haja esse engajamento educativo-musical, é imprescindivel o conhecimento musical do professor, uma vez que este tem o papel de ajudar as pessoas a aprofundarem os significados do seu próprio discurso musical na relação com o outro. Essa parece ser a compreensão dos colaboradores da pesquisa, pela imagem que fazem daquele professor que cuida, que brinca e que ensina música ao mesmo tempo, como bem lembra Minnie: "O que eu mais vou lembrar são as bagunças e os amigos que eu fiz aqui, as brincadeiras, as coisas na aula de música. E a professora... eu vou lembrar muito dela". Nesta direção, Dorinha conclui: "Eu vou sentir falta principalmente dos professores, que são a melhor coisa que tem aqui".

Essa relação afetiva dos professores com as crianças é chamada por Abramowski (2010), citada por Abreu (2011), de carinho público. Nesse aspecto, o professor não direciona o carinho pelo aluno para o lado pessoal, mas para a sua condição de aluno. É uma afetividade que dá condições de facilitar a tarefa específica da escola, que é a de ensinar, neste caso, música (Abreu, 2011, p. 115).

Além do carinho público, trazido nas narrativas com palavras como amor e alegria, os colaboradores idealizam o tipo de professor que gostariam que a escola tivesse. Sugerimos, durante as rodas de conversa, que os colaboradores construíssem suas narrativas dando ideias para o personagem Thor, que vive em Asgard, lembrando aos colaboradores que, nesse planeta onde vive o Thor, não há escolas. Esse fantasiar a realidade, como explica Sarmento (2004), faz parte da construção da criança, da sua visão discutida do mundo e da atribuição do significado às coisas. Portanto, este processo de imaginação do real é fundacional do modo de inteligibilidade, isto é, como compreendem determinada situação.

Mônica, uma das crianças colaboradoras, explicou como gostaria que fosse esse professor ideal: "Ele tem que ter muita alegria e muito amor pelas crianças, porque tem professores que a criança fica conversando só um pouquinho e ele briga muito". Outra criança, Denise, exemplifica: "Uma pessoa está conversando, ao invés de você falar brigando tipo: 'para de conversar', você fala com jeito: 'por favor, eu estou dando a minha aula, você vai parar de conversar? Ser educado". Minnie, colaboradora da pesquisa, também traz narrativas a esse respeito: "Eu gosto muito da professora, mesmo ela brigando. Ela briga muito com a gente. Eu gosto muito dela porque ela explica direitinho". Por fim, a colaboradora Carmem acredita que o professor precisa ter muita "concentração e paciência", o que, nas palavras de Isadora, significa "saber lidar com confusões".

Olhar para o que os colaboradores pensam, a partir de si mesmas, sobre as relações de professores e crianças e sobre o agir destes atores em sala de aula, permite, como esclarece Sarmento (1997), descortinar uma realidade que emerge das interpretações infantis dos respectivos mundos da vida. Esse mundo da vida que é a sala de aula, visto a partir do olhar das crianças, permite revelar fenômenos obscurecidos pelo olhar de muitos professores. 
Desse modo, é preciso ouvir as crianças lentificando uma escuta atenta e sensivel. Esse lentificar, segundo as palavras de Larrosa Bondia (2002, p. 24), "em que se requer um gesto de interrupção, um gesto que é quase impossivel nos tempos que correm: requer parar para pensar, parar para olhar, parar para escutar, pensar mais devagar, olhar mais devagar, e escutar mais devagar".

Como sujeitos de direito, colaboradores da pesquisa se permitem dar conselhos aos professores:

Eu aconselharia os professores também a não faltarem, não atrasarem, não maltratarem as crianças, serem sempre alegres, bons e terem uma saúde boa (Denise).

Eu aconselharia também que tivesse muitos professores bons, e tinha que ter aquele que tivesse alegria de ser professor, chegar pontualmente, nunca viajar, igual a Denise disse, nunca poder faltar, não pode maltratar (Flash).

Os professores viajarem até pode... (Denise).

Tem que levar a gente (Flash).

Só que tem que chegar a tempo para dar aula, né?! (Denise).

Deixar a gente tocar os instrumentos que a gente quiser (Capitão América).

Não só como as professoras brincam só com os pequenininhos, podia brincar com os adultos também, com os maiores também porque elas brincam mais, riem mais com os pequenininhos. Elas podiam rir também com a gente, brincar, se divertir, sair mais com a gente. Também quando a gente vai para o quinto ano, como a gente está agora, a gente podia se divertir com as nossas próprias professoras (Minnie).

Outro conselho dado por Franjinha se refere às competências e habilidades de professores de música: "Ele precisa tocar, acho, quase todos os instrumentos". Essa sugestão de Franjinha sobre as propostas para a aula de música é ampliada com outras ideias que os demais colaboradores trazem em suas narrativas:

Eu ia sugerir algumas salas bem grandes para os professores. É... pegarem os alunos e fazerem umas coisas bem legais, [...] quando for no carnaval ou na Páscoa, enfeitar bem a sala (Mônica).

Precisa de ter, por exemplo, sei lá, uma música para dar exemplo como a tia faz aqui, ela passa a música no computador e depois a gente tem que pegar o ritmo (Pipa). 
Ele tem que ensinar a tocar mais, um pouco mais de instrumentos, aí a gente combina, um dia, de sempre no final da aula fazer uma brincadeira, senão, fica chato só fazer aula. Tem que ensinar, tem que ensinar a cantar, tem que ensinar as notas musicais, a tocar as coisas... e a brincadeira da nota musical (Flash).

Sobre o professor, ele poderia também dar mais instrumentos, porque tem várias coisas que as pessoas não conseguem [...]. Ah, e também [ensinar] a gente a cantar nos finais das aulas, como fazer uma brincadeira de quem acerta a música, cantar (Magali1).

Poderia ser um professor ou professora divertido, e também que ensinasse músicas diferentes, ensinasse vários tipos de instrumentos e poderia até ter instrumentos diferentes, que a gente nem conhecesse (Marina2).

Ao fazerem música brincando, as crianças participam da experiência sonora num tempo de conexões significativas entre os acontecimentos, suspendendo o automatismo das ações para entrar em relação com o som. É, portanto, no ato de brincar que as crianças tomam contato consigo mesmas, com o outro, experimentando a interdependência existente entre a música dada e a escuta atenta permeada pelas brincadeiras. Dito com as palavras de Flash, "de sempre fazer uma brincadeira na aula".

Para Sarmento (2004), a ludicidade constitui um traço fundamental das culturas infantis e para elas não há distinção entre brincar e fazer coisas sérias. Isso me ajudou a perceber que, nas narrativas, os colaboradores associavam a diversão com suas aprendizagens nas aulas que, para eles, eram essencialmente brincadeiras. Na EP há uma intenção, por parte de alguns professores, de que as crianças aprendam brincando. Por isso, as aulas são "muito boas", e, de acordo com as narrativas dos colaboradores, ter uma aula prazerosa é a melhor maneira de aprender.

Essas narrativas dos colaboradores nos remetem a alguns pais de alunos que sustentam que a EP não tem importância porque as crianças só vão para brincar. Isto nos leva a pensar que esses pais não fazem relação da ludicidade com a aprendizagem.

Ao que parece, o que esses pais demonstram é um desconhecimento do ideário de Anísio Teixeira, que, de acordo com Lipai (2004), definia a aprendizagem como um processo ativo, em que os interesses da criança devem ser a fonte de inspiração das atividades escolares. Anísio também defendia duas ideias básicas: a gratuidade, a acessibilidade a todos da escola pública e a necessidade de implantação de experiências práticas em todos os niveis de conhecimento. Para que essas ideias acontecessem, seriam necessários três pontos básicos: o lúdico, o trabalho e o conhecimento acadêmico. 
Esse tripé, que fundamenta a formação global do aluno para o mundo da vida e do trabalho, é permeado pelo conhecimento científico. E isso significa considerar que a Arte, mais especificamente a música-objeto deste estudo, consiste deste tripé. Ou seja, é uma área de conhecimento científico, também gera trabalho ou pode sinalizar caminhos profissionais para o aluno de educação básica e, por fim, proporciona ludicidade. Esse, no entendimento de Anísio Teixeira, é um tripé que se retroalimenta, não considerando um melhor do que outro, mas entendendo que os três funcionam em conjunto.

As narrativas das crianças colaboradoras evidenciam que esse tripé é fundamental na sua formação, como podemos observar na narrativa de Flash: "Tem que ensinar, tem que ensinar a cantar, tem que ensinar as notas musicais, a tocar as coisas... e brincadeira da nota musical".

Analisando a importância da dimensão lúdica nos processos de aprendizagem escolar como uma das condições para o desenvolvimento das crianças e dos adolescentes, Macedo, Petty e Passos (2007) fazem duas suposições: a primeira é que a compreensão dos processos de desenvolvimento e aprendizagem, como formas interdependentes de conhecimento, poderia recuperar esses sentidos da escola que se perderam com o tempo, e a segunda suposição é que teríamos de cuidar da dimensão lúdica das tarefas escolares, possibilitando às crianças serem protagonistas das suas ações, dentro dos limites de suas possibilidades de desenvolvimento e dos recursos mobilizados pelos processos de aprendizagem. Em uma escola para todos, desenvolvimento e aprendizagem devem ser considerados como formas interdependentes, e a condição para isso é que a dimensão lúdica qualifique as tarefas escolares. No brincar, os autores esclarecem que

Os objetivos, meios e resultados tornam-se indissociáveis e
enredam a criança em uma atividade gostosa por si mesma,
pelo que proporciona no momento de sua realização. Este é o
caráter autotélico do brincar. Do ponto de vista do
desenvolvimento, essa característica é fundamental, pois
possibilita à criança aprender consigo mesma e com os objetos
ou pessoas envolvidas nas brincadeiras, nos limites de suas
possibilidades e de seu repertório (Macedo; Petty; Passos,
2007 p. 14).

Diante do exposto, as histórias que os colaboradores nos contam sobre a EP é a de um lugar acolhedor, comparado, por alguns colaboradores, com a sua própria casa. Há também, por parte deles, uma vontade de que esse espaço seja ampliado, proporcionando maior inclusão. O afeto é um componente muito importante para esses colaboradores, tanto que, quando se referem ao professor ideal, se expressam com palavras como amor, alegria e carinho.

A escola é também um lugar que possui um tempo finito, mas que, nesse tempo, é capaz de promover aprendizagens que vão sendo construídas para fazer "muitas coisas". Esse fazer, por sua vez e nas palavras dos 
colaboradores, consiste em tocar, jogar, divertir, brincar, aprender, saber e apresentar. Dentre essas palavras, a que mais se destaca é "a Escola Parque é para ser divertida". Uma escola, como diria Anísio Teixeira, com vida.

\section{CONSIDERAÇÕES FINAIS}

Diante dos pequenos enredos construídos com as crianças colaboradoras da pesquisa, compreendemos, pelas narrativas das crianças, os tipos de escola e de aula de música desejadas: uma escola divertida, que acolhe, que ensina musicalmente e que constrói valores para a vida. É o sentido da escola com música que nos leva a pensar em uma educação musical escolar preocupada com o sujeito que, nos processos criativos musicais, seja tocando ou cantando, faça música de forma divertida.

E como seria um fazer musical divertido? Bom, para as crianças colaboradoras da pesquisa, o professor precisa rir mais, se divertir mais, ter a alegria de viver a profissão e se divertir junto com o aluno. Para eles, este é o maior tesouro. E, parafraseando Delory-Momberger (2012, p. 526), o tesouro consiste em trilhar caminhos empreendendo um trabalho de autoria e do que contam os relatos de outros autores. "É pouco e é muito, é o seu tesouro".

As relações que essas as crianças colaboradoras constroem com a escola é a de um lugar acolhedor, comparado, por muitos, com a sua própria casa. Talvez seja por isso que eles narram tanto sobre o afeto, levando-nos a pensar que o professor ideal é aquele que se expressa com palavras de amor, alegria e carinho.

As narrativas mostraram também que a escola é um lugar que possui um tempo finito, mas que nesse tempo é capaz de promover aprendizagens que vão sendo construídas, como diria Teixeira (1975), com vida. Talvez seja por isso que o motivo recorrente nas narrativas é que a aula seja concluída sempre com brincadeiras. Isso parece explicar que os pilares que sustentam o trabalho do professor não estão apartados da vida, mas integrados a ela. Assim, faz sentido que cada final de aula de música seja permeado de alegria.

Ao responder os objetivos da pesquisa que consistiram em compreender como as crianças dos anos iniciais das EPs de Brasília veem as aulas de música, ficou evidente que esses pequenos enredos trouxeram aspectos relacionados à história desses colaboradores com a escola. Eles assimilaram a música ensinada na escola, ou seja, transformaram essa música em algo próprio, localizando-se, assim, no tempo e no espaço escolar experienciado por eles. Portanto, acreditamos que as narrativas infantis escutadas poderão gerar um novo modo de ouvir histórias produzidas no espaço escolar com crianças e com músicas.

Isso possibilita que ideias, proposições e, quem sabe, conceitos e principios possam emergir conhecimentos gerados a partir das narrativas infantis e, assim, contar novas histórias com músicas, professores e crianças. 


\section{REFERENCIAS}

ABRAMOWICZ, A. A pesquisa com crianças em infâncias e a sociologia da infância. In: FARIA, A. L. G.; FINCO, D. (Orgs.). Sociologia da Infância no Brasil. Campinas, SP: Autores associados, 2011.

ABREU, D. V. Tornar-se professor de música na educação básica: um estudo a partir de narrativas de professores. Tese (Doutorado em Música) Programa de Pós-Graduação em Música, Instituto de Artes, Universidade Federal do Rio Grande do Sul, Porto Alegre, 2011.

ALHEIT, P. Biografização como competência-chave na modernidade. Revista da FAEEBA - Educação e Contemporaneidade, Salvador, v. 20, n. 36, p. 3141, jul./dez. 2011.

BENJAMIN, W. O narrador: considerações sobre a obra de Nikolai Leskov. In: BENJAMIN, W. Magia e técnica, arte e politica: obras escolhidas. Vol. 1. 7. ed. São Paulo: Brasiliense, 1987.

DELORY-MOMBERGER, C. Os desafios da pesquisa biográfica em educação. In: SOUZA, Elizeu C. (Org.). Memória, (auto)biografia e diversidade: questões de métodos e trabalho docente. Salvador: EDUFBA, 2011. p. 43-58.

DELORY-MOMBERGER, C. Abordagens metodológicas na pesquisa biográfica. Revista Brasileira de Educação, v. 17, n. 51, p. 523-740, set./dez. 2012.

HEINKEL, D. Ser criança é ir à escola, ter amigos de montão: a escuta da infância em seu "oficio de aluno". 141 f. Dissertação (Mestrado em

Educação) - Departamento de Pedagogia, Universidade Regional do Noroeste do Estado do Rio Grande do Sul, Ijuí, 2010.

LARROSA, B. J. Notas sobre a experiência e o saber de experiência. Revista Brasileira de Educação, Rio de Janeiro, n. 19, p. 20-28, jan./abr. 2002.

LIPAI, A. E. Uma arquitetura para o fluir da vida. Integração, São Paulo, n. 37, p. 135-141, 2004.

MACEDO, Lino de; PETTY, Ana Lúcia Sícoli; PASSOS, Norimar Christe. Os Jogos e o lúdico na aprendizagem escolar. Porto Alegre: Artmed, 2007.

MERRIAM A. P. The Anthropology of Music. Evanston, USA: Northwestern University, 1964.

MOURA, A. F.; LIMA, M. G. A reinvenção da roda: roda de conversa: um instrumento metodológico possivel. Revista Temas em Educação, João Pessoa, v. 23, n. 1, p. 98-106, jan./jun. 2014.

PASSEGGI, M. C. Memórias de Pesquisa-Formação: Cenários, tempos, personagens e enredo. In: PASSEGGI, Maria da Conceição; BARBOSA, 
Tatyana M. N. (Org.). Memórias, memoriais: pesquisa e formação docente. Natal: EDUFRN; São Paulo: Paulus, 2008. p. 27-42.

PASSEGGI, M. C. Nada para a criança sem a criança: o reconhecimento de sua palavra para a pesquisa (auto)biográfica. In: MIGNOT, A. C.; SAMPAIO, C. S. S.; PASSEGGI, M. C. (Orgs.). Infância, aprendizagem e exercício da escrita. Curitiba: CRV, 2014. p. 133-148.

PEDRINI, J. R. Sobre aprendizagem musical: um estudo de narrativas de crianças. 131 f. Dissertação (Mestrado em Educação) - Programa de PósGraduação em Educação do Faculdade de Educação, Universidade Federal do Rio Grande do Sul, Porto Alegre, 2013.

PINTO, M.; SARMENTO, M. J. As crianças e a infância: definindo conceitos, delimitando o campo In: PINTO, M.; SARMENTO, M. J. (Coords.). As crianças: contextos e identidades. Braga: Universidade do Minho, 1997.

PONSO, C. C. Música na escola: concepções de música das crianças no contexto escolar. 94 f. Dissertação (Mestrado em Educação) - Programa de Pós-Graduação da Universidade Federal do Rio Grande do Sul, Porto Alegre, 2011.

SARMENTO, M. J. As Culturas da Infância nas Encruzilhadas da Segunda Modernidade. In: SARMENTO, Manuel Jacinto; CERISARA, Ana Beatriz. Crianças e Miúdos: Perspectivas Sociopedagógicas da Infância e Educação. Porto, Portugal: Asa Editores, 2004.

SWANWICK, Keith. Ensinando Música Musicalmente. Trad. Alda Oliveira e Cristina Tourinho. Moderna: São Paulo. 2003.

TEIXEIRA, A. S. Pequena introdução à filosofia da educação. 7. ed. São Paulo: Companhia Editora Nacional, 1975. 
Olívia Augusta Benevides Marques possui Mestrado em Música pela Universidade de Brasília (2016). Especialização em Arte, Educação e Tecnologias Contemporâneas - Arteduca pela Universidade de Brasília (2009). Licenciatura em música pela Universidade de Brasília (1995) Tem experiência na área de Música, com ênfase em Música.

Delmary Vasconcelos de Abreu possui Doutorado em Música pela Universidade Federal do Rio Grande do Sul (2011). Mestrado em Estudos de Linguagem pela UFMT (2006). Licenciatura em música pelo Centro Universitário Metodista (2010) e em Letras pela Universidade do Estado de Mato Grosso (1998). Atua como docente nos cursos de licenciatura em música presencial e a distância e no programa de pós-graduação "Música em Contextos"; da Universidade de Brasília. Tem experiência na área de Educação Musical, atuando principalmente nos seguintes temas: profissionalização da docência em música, narrativas de profissionalização em música, educação musical escolar, ensino a distância e canto popular. Atualmente é pós-doutoranda em Educação na linha de pesquisa: cultura escrita, linguagens e aprendizagens na Universidade Federal de Pelotas/RS. 